\title{
Identification of mRNAs differentially-expressed between benign and malignant breast tumour cells
}

\section{Liu', PS Rudland', DR Sibson ${ }^{2}$ and R Barraclough*,1}

'School of Biological Sciences, Life Sciences Building, University of Liverpool, PO Box 147, Liverpool L69 7ZB, UK; ${ }^{2}$ Clatterbridge Cancer Research Trust, JK Douglas Laboratories, Clatterbridge Hospital, Bebington, Wirral CH63 4JY, UK

Two suppression subtracted cDNA libraries have been constructed, one containing cDNAs to mRNAs present at a higher level in a benign human breast tumour-derived cell line relative to the malignant mammary cell line, MCF-7, and the other containing cDNAs present at a higher level in the MCF-7 cells relative to the benign cells. Randomly-picked cloned DNAs have been sequenced yielding 29 and 128 different cDNAs from the benign and malignant libraries, respectively. Using reverse Northern hybridisation, $76 \%$ and $83 \%$ of the cDNAs were differentially expressed by greater than two-fold, whilst $14 \%$ and II\% of cDNAs in the respective libraries were differentially expressed by more than 15-fold. Amongst these were oestrogenresponsive cDNAs and expressed sequence tags. One such oestrogen-responsive expressed sequence tag, M4I, is transcribed from a gene located on chromosome 2 lq22.3, within an intron of a larger gene. The M4I gene contains oestrogen response elements, one of which is associated with alu repeats. M4I mRNA is expressed at a statistically significantly higher level in human breast cancer specimens than in normal human breast and benign lesions. In carcinomas, its up-regulation is associated with the development of the malignant cell.

British Journal of Cancer (2002) 87, 423-43I. doi:I0.1038/sj.bjc.6600456 www.bjcancer.com

(c) 2002 Cancer Research UK

Keywords: suppression subtraction hybridisation; oestrogen receptor; chromosome 21; breast cancer

Cancer in the Western world affects one in three of the population, and it is the malignant properties of invasion and metastasis that are harmful to the patient. Many cancers are thought to arise from tumours, which progress from a benign state to a malignant one (Nowell, 1986). The benign tumours can arise by a variety of mechanisms including changes in gene expression and mutation of key growth regulatory genes; however, the progression of a tumour to a life-threatening malignant state involves more-widespread changes in gene expression (Fearon and Vogelstein, 1990). Thus, the difference between the behaviour of benign tumour cells and cancer cells is likely to be explained, at least in part, by identifying the genes and gene products which are differentially expressed between them (Martin et al, 2000). Such an approach has yielded the metastasis-inducing protein S100A4 (Davies et al, 1993; Barraclough, 1998). In order to identify a wider range of mRNAs encoding protein products which might contribute to the progression of oestrogen receptor positive breast tumour cells, PCR -selected suppression subtractive hybridisation has now been employed to construct subtracted libraries in alternative orientations using mRNAs isolated from a benign human mammary epithelial cell line, Huma 123 (Ke et al, 1993), and from the malignant human mammary epithelial cell line, MCF-7. The resulting subtracted libraries not only contain previously-characterised differentially-expressed cDNAs associated with the presence of oestrogen receptor, but also contain novel cloned cDNAs which may also be associated with the development of breast cancer.

*Correspondence: R Barraclough; E-mail: brb@liv.ac.uk

Received 7 January 2002; revised 8 May 2002; accepted 13 May 2002

\section{MATERIALS AND METHODS}

\section{Human breast cell lines}

Huma 7, a normal human mammary epithelial cell line that had been immortalised with SV40 virus (Rudland et al, 1989), Huma 123, a benign human mammary epithelial cell line, and Huma 109, a benign human mammary elongated myoepithelial-like cell line, derived from a primary cell culture of human fibrocystic disease displaying prominent epithelial hyperplasia (Briand et al, 1987; Ke et al, 1993), and the malignant human mammary epithelial cell lines, MCF-7, T47D, and ZR-75-1, derived from pleural effusions of breast cancer patients (Soule et al, 1973; Engel and Young, 1978) and MDA-MB-231 (Cailleau et al, 1974) were propagated in a humidified atmosphere of $95 \%$ air, $5 \% \mathrm{CO}_{2}$ at $37^{\circ} \mathrm{C}$ as described below. The Huma 7 cell line was grown in DMEM, 5\% $\left(\mathrm{v} \mathrm{v}^{-1}\right)$ foetal calf serum (FCS), $50 \mathrm{ng} \mathrm{ml}^{-1}$ each of insulin and hydrocortisone. The benign cell lines were grown in 50\% DMEM, 50\% RPMI 1640 medium, 5\% $\left(\mathrm{v} \mathrm{v}^{-1}\right)$ FCS, $50 \mathrm{ng} \mathrm{ml}^{-1}$ insulin, $5 \mathrm{ng} \mathrm{ml}^{-1}$ EGF (Rudland et al, 1989; Ke et al, 1993). Cell line MCF-7 was propagated in DMEM, 5\% $\left(\mathrm{v} \mathrm{v}^{-1}\right) \mathrm{FCS}, 50 \mathrm{ng} \mathrm{ml}^{-1}$ insulin, $10^{-8} \mathrm{M}$ oestradiol; T47D in DMEM, $10 \%\left(\mathrm{v} \mathrm{v}^{-1}\right)$ FCS, $1 \mu \mathrm{g} \mathrm{ml}^{-1}$ insulin, $2.5 \mathrm{ng} \mathrm{ml}^{-1}$ EGF; ZR-75-1 in DMEM, 5\% $\left(\mathrm{v} \mathrm{v}^{-1}\right)$ FCS, $2.5 \mathrm{ng} \mathrm{ml}^{-1}$ EGF, $10^{-8} \mathrm{M}$ oestradiol. The MDAMB-231 cell line was propagated in DMEM, 5\% $\left(\mathrm{v} \mathrm{v}^{-1}\right)$ FCS, $50 \mathrm{ng} \mathrm{ml}^{-1}$ insulin, $2.5 \mathrm{ng} \mathrm{ml}^{-1}$ EGF. Media used for growing cells contained phenol red. Cell lines were grown in the same batch of foetal calf serum and harvested when they reached $70 \%$ confluence. MDA-MB-231 cells were growing slightly faster than Huma 7, Huma 109, MCF-7, T47D, ZR-75-1, and Huma 123 were growing slightly more slowly than the others. Broadly, however, the cells were growing at a similar rate. 
The Huma 123 cells, used for the construction of the subtracted libraries, are a unique single-cell cloned line derived from a primary culture of human benign fibrocystic disease. The cell line has been characterised as a breast epithelial cell by immunochemical detection of breast epithelial-associated antigens, epithelial membrane antigen, milk fat globule membrane antigen and keratin 18 in cell culture and in tumours produced in immunosuppressed $n u-n u$ mice. In culture, the cells are diploid both in culture and when growing in tumours in $n u-n u$ mice. They possess regular nuclei with little or no pleomorphism, consistent with a nonmalignant morphology. The tumours are encapsulated and show no evidence of local invasion or dissemination. Huma 123 cells thus have the characteristics of a neoplastic but not malignant phenotype (Ke et al, 1993; Rudland, 1993). The Huma 123 cell line has not been manipulated in order to make it immortal for culture purposes. Since it is difficult to obtain cultures of normal/benign human breast epithelial cells, the Huma 123 cell line is uniquely suited for comparison with more malignant cells for studies into the early stages of the development of malignancy.

\section{Construction of subtracted cDNA libraries between human breast tumour cell lines, Huma 123 and MCF-7}

Suppression subtracted libraries were constructed using a PCRSelect ${ }^{\mathrm{TM}}$ cDNA Subtraction Kit (Clontech, Palo Alto, CA, USA), according to the manufacturer's methodology. Critical steps of the construction of the libraries were checked before proceeding to the next step. Double-stranded cDNAs of both tester and driver were synthesised from $2 \mu \mathrm{g}$ poly $(\mathrm{A})^{+}$-containing RNA derived from the cultured benign cell line, Huma 123 and the malignant cell line MCF-7. The efficiencies of double-stranded cDNA synthesis and digestions with restriction enzyme RsaI were monitored by agarose gel electrophoresis. The two portions of fragmented ds cDNAs of tester, ligated with different specific adaptors (1 and 2) were subjected to hybridisation with the fragmented ds cDNA of driver. After suppression PCR amplification, the resulting subtracted PCR pools of benign or malignant subtracted libraries ranged in size from $200 \mathrm{bp}$ to $1 \mathrm{kbp}$. The PCR products constituting the subtracted libraries were ligated into a ddT-tailed pBluescript vector, and transformed into E. coli XL-1 blue bacteria by electroporation, followed by plating on agar containing ampicillin, IPTG and X-gal. More than $90 \%$ of the randomly-picked clones contained cDNA inserts.

\section{DNA sequencing analysis of the subtracted libraries}

Nucleic acid sequences of cDNA clones from the benign and malignant subtracted libraries were determined using an automated ABI 377 DNA sequencing system and standard dye terminator AmpliTaq kits (Perkin Elmer, Buckinghamshire, UK). The resulting DNA sequences were analysed for homology using the public GenBank/EMBL/DDBJ/PDB and Expressed Sequence Tag (EST) databases using the Basic Local Alignment Search Tool (BLAST) program (http://www.ncbi.nlm.nih.gov/BLAST) (Altschul et al, 1990). The DNA sequences were further analysed using the GCG program (University of Wisconsin, WI, USA).

\section{Differential screening of the subtracted libraries using reverse Northern blot}

The cloned cDNA inserts were amplified directly from individual colonies of both subtracted benign and malignant libraries using colony PCR. After amplification, PCR products were denatured and spotted onto duplicate nylon membranes using a slot- or dot-blot apparatus. The filters were hybridised with equal concentrations of double-stranded cDNA derived from driver and tester mRNA, respectively, which had been labelled to approximately equal specific activity $\left(1 \times 10^{9}\right.$ d.p.m $\mu \mathrm{g}^{-1}$ DNA $)$ with ${ }^{32} \mathrm{P}$-dCTP as described previously (Feinberg and Vogelstein, 1984).

\section{RNA electrophoresis and Northern hybridisation}

Gel electrophoresis of RNA in formaldehyde denaturing gels and Northern blotting were performed according to standard procedures (Sambrook et al, 1989). The filters were hybridised with equivalent amounts of cloned double-stranded cDNA labelled as above. The intensities of the autoradiographic images were quantified using IMAGE software (NIH, Bethesda, MD, USA).

\section{Rapid amplification of cDNA ends for cloning of full length cDNA}

Cloning of full length M41 cDNA was carried out by rapid amplification of cDNA ends (RACE) using a Marathon cDNA amplification Kit (Clontech) on $2 \mu \mathrm{g}$ of poly $(\mathrm{A})^{+}$-containing RNA derived from the MCF-7 cell line. The resulting adaptorligated ds cDNA, which represented an uncloned ds cDNA library, was used to perform $5^{\prime}$ and $3^{\prime}$ RACE reactions with the following M41 gene specific primers for $5^{\prime}$ and $3^{\prime}$ RACE reactions respectively: (5'-CCTCACGCTGTCTGGTTGGCTTTCC- $\left.3^{\prime}\right), \quad\left(5^{\prime}\right.$ GGTATGCAGCTGATAAGACGCTATAGAG- $3^{\prime}$ ), based on the isolated M41 EST sequence.

\section{Human breast tissue, immunocytochemistry and in situ hybridisation}

Normal and benign human breast specimens and invasive ductal carcinomas were obtained from the Liverpool Cancer Tissue Bank Research Centre and the Royal Liverpool University Hospital (Liverpool, UK) with legal consent as described previously (Taylor et al, 1998). Immunocytochemical detection of oestrogen receptor $\alpha$ (Platt-Higgins et al, 2000), in situ hybridisation and PCR reactions (Liu et al, 2000) were carried out as described previously.

\section{RESULTS}

\section{Construction of subtracted cDNA libraries}

Libraries of cDNAs from the benign Huma 123 cells, suppression subtracted with cDNA from MCF-7 cells (benign library), and from the MCF-7 cells suppression subtracted with cDNA from the Huma 123 cells (malignant library) were constructed. The subtraction procedure reduced the abundancies of glyceraldehyde3-phosphate dehydrogenase (GAPDH) cDNA in the malignant and benign subtracted libraries about 36 -fold and 40 -fold, respectively, relative to their abundancies in the unsubtracted cDNAs, as indictated by Southern hybridisation of PCR-amplified GAPDH cDNA.

Overall, $87 \%$ of the randomly-picked cloned cDNAs yielded sequence information. 128 sequences (comprising 72 different known cDNAs, 53 expressed-sequence-tags (ESTs) and three unmatched sequences) and 29 sequences (comprising 19 separate known cDNAs, eight ESTs and two novel sequences) were obtained from 174 and 52 sequenced cDNA clones from the malignant and benign subtracted libraries, respectively.

\section{Differential screening of the subtracted libraries using reverse Northern hybridisation}

The relative levels between the Huma 123 and MCF-7 cells of the mRNAs corresponding to the sequenced cloned cDNAs, isolated from the subtracted benign and malignant libraries, were estimated by reverse Northern hybridisation, using as probes, cDNA produced from mRNA from either the Huma 123 or MCF-7 cells. The hybri- 
disation results were normalised using cDNAs corresponding to mRNAs for 36B4 (Laborda, 1991) and glyceraldehyde-3-phosphate dehydrogenase (GAPDH), both of which show similar expression between the Huma 123 and MCF-7 cell lines. Using an expression ratio of over two-fold as cut-off, 22 of the 29 cDNA clones, and 99 of 119 cDNA clones examined by reverse Northern screening were identified in the benign and malignant subtracted libraries, respectively (Table 1). The identities of these cDNAs are shown in Table 2. The fact that these totals of cDNAs differentially-expressed by more than two-fold represent respectively $76 \%$ and $83 \%$ of the total cDNAs examined shows that the subtractive hybridisation procedure was yielding predominantly differentially expressed cDNAs.

Four and 13 cDNAs were differentially expressed by over 15 -fold in the benign and malignant breast tumour cell lines, respectively (Tables 1 and 2). Amongst the cDNAs expressed at a higher level in the MCF-7 cells than in the Huma 123 cells were previously characterised oestrogen-responsive genes, including pLIV-1 (Manning et al, 1988) (nine-fold), pS2 (Masiakowski et al, 1982) (20-fold) and Cyclin D1 (Altucci et al, 1996) (15-fold), consistent with the malignant breast cancer-derived MCF-7 cell line being immunocytochemically positive, and the benign Huma 123 cell line being immunocytochemically negative, for oestrogen receptor $\alpha$ (not shown).

\section{Clone M41}

Clone M41, corresponded to an expressed sequence tag that represented an mRNA that was expressed at a 17-fold higher level in the mRNA from the MCF-7 cells than in the Huma 123 cells (Table 2). In Northern hybridisation experiments, the M41 probe hybridised to a major band of RNA of $0.9-1.3 \mathrm{~kb}$ from the MCF-7 cells, but there were two additional, but fainter bands of hybridisation at $1.8 \pm 0.1 \mathrm{~kb}$ and $3.8 \pm 0.1 \mathrm{~kb}$ (Figure 1). M41 mRNA was abundantly expressed in RNA from oestrogen receptor-positive mammary cell lines, T47-D, ZR-75, but was completely undetectable in oestrogen-receptor-negative cell lines, the malignant human mammary cell line, MDA-MB-231 and the benign mammary-derived cell lines Huma 123. M41 mRNA was also undetectable in the normal-derived and benign human mammary epithelial cell lines, Huma 7 and Huma 109 (Figure 1).

The sequence of M41 is located on the human genomic contig GenBank NT_011512.3, which contains 28515322 bp of cloned DNA from chromosome 21q22.3. Using RACE reactions to identify $5^{\prime}$ and $3^{\prime}$ regions of the M41 mRNA, $3^{\prime}$ RACE yielded 10 separate products, each of which corresponded to one of four patterns, which precisely matched the NT_011512.3 genomic DNA sequence to the poly $(\mathrm{A})^{+}$addition sequence. $5^{\prime}$-RACE yielded 16 cloned

Table I Summary of differentially-expressed clones between the benign and malignant subtracted libraries using reverse Northern hybridisation

\begin{tabular}{lcc}
\hline & \multicolumn{1}{c}{$\begin{array}{c}\text { Number of cloned } \\
\text { CDNAs sequenced }\end{array}$} \\
\cline { 2 - 3 } & $\begin{array}{c}\text { Benign } \\
\text { subtracted } \\
\text { library }\end{array}$ & $\begin{array}{c}\text { Malignant } \\
\text { subtracted } \\
\text { library }\end{array}$ \\
\hline Level of differential expression & 4 & 13 \\
Highly differentially expressed clones (> |5-fold) & 3 & 21 \\
$\begin{array}{l}\text { Significant differentially expressed clones } \\
(5-\mid 4.9-f o l d)\end{array}$ & 15 & 65 \\
$\begin{array}{l}\text { Differentially expressed clones (2.0-4.9-fold) } \\
\text { Hardly detectable or not differentially expressed } \\
\text { clones (<2.0-fold) }\end{array}$ & 7 & 20 \\
$\begin{array}{l}\text { Total number of differentially expressed cDNAs } \\
\text { identified }\end{array}$ & 22 & 99 \\
$\begin{array}{l}\text { Total number of cloned cDNAs examined } \\
119\end{array}$ & 29 & \\
\hline
\end{tabular}

sequences, each of which corresponded to one of seven patterns, which matched precisely the NT_011512.3 genomic DNA sequence. Taken together these results identified at least seven experimentally-determined alternatively-spliced transcripts of M41 mRNA in the MCF-7 RNA (M41, A1-7, GenBank accession numbers:AF401029, AF401030, AF401031, AF401032, AF401033, AF401034, AF401035) containing up to three introns (Figure 2).

Genomic DNA in the region of M41 in contig NT 011512.3 contained two $\mathrm{Alu}$ repeat sequences, $264 \mathrm{bp}$ and $286 \mathrm{bp}$ in length respectively, located between 27328305 and 27328568 and between 27329569 and 27329854, upstream and adjacent to two of the proposed exons of the M41 gene. There are two oestrogenresponse-elements (ERE): AGGTCA- $\mathrm{N}_{23}$-TGACCT and AGGTCA$\mathrm{N}_{17}$-TGACC and one half ERE located between 27326764 and 27326797, 27328299 and 27328305, and between 27329636 and 27329663, of contig NT_011512.3 sequence (Figure 2), consistent with the abundance of M41 mRNA in the ER positive cells lines (Figure 1).

The gene for M41 does not presently occur in the annotated human genome sequence. Thus, mapping of contig NT_011512.3 onto the published complete GenBank sequence of human chromosome 21 placed the M41 sequence between nucleotides $40864055 \mathrm{bp}$ and $40866330 \mathrm{bp}$, located between existing known genes, PCP4 at 40348176 bp and BACE2 at $41649179 \mathrm{bp}$ (Table $3)$ at a previously unmapped location. However, contig NT_011512.3 also contains part of a previously described gene, Down Syndrome Cell Adhesion Molecule (DS-CAM, cDNA accession AF023450; protein accession, AAC17967) on the complementary strand in the region of the M41 gene. The M41 coding region is located on the complementary strand within the $323 \mathrm{kbp}$ intron 2 of this gene (Figure 2).

In order to find out whether M41 mRNA is expressed in human tumour specimens, in situ hybridisation was carried out (Figure 3) using sense and antisense probes derived from the region of the M41 clone spanning two exons (Figure 2). Whereas there was no hybridisation to any of the specimens with the sense probe, the

\section{A}
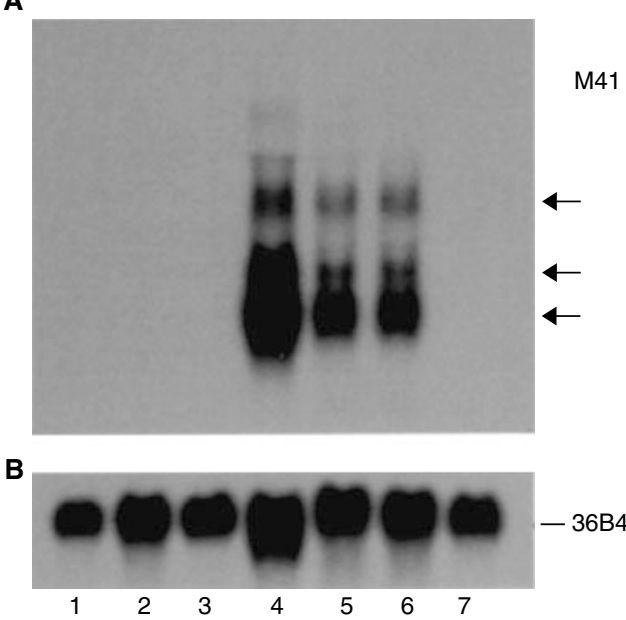

Figure I Occurrence of M4I mRNA in human breast tumour cell lines. Total RNAs were isolated from the SV40-immortalised normal human mammary cell line, Huma 7 (lane I), an elongated converted cell line, Huma 109 (lane 2) derived from the benign mammary tumour-derived cell line Huma 123 (lane 3), the malignant mammary epithelial cell lines MCF-7 (lane 4), T47-D (lane 5), ZR-75 (lane 6) and MDA-MB-23I (lane 7). These RNAs were subjected to Northern hybridisation as described in Materials and Methods, using a ${ }^{32} \mathrm{P}$-labelled probe to $\mathrm{M} 4 \mathrm{I}$ mRNA $(\mathbf{A})$ or to ribosomal phosphoprotein, 36B4, mRNA (B) to check for the loading of RNA onto the gel. The arrows point to three bands of hybridisation in the three oestrogen receptor positive human breast cancer cell lines. 
Table 2 cDNAs differentially expressed between benign and malignant human breast cell lines

cDNAs more highly expressed in the benign subtracted library

\begin{tabular}{|c|c|c|c|}
\hline \multicolumn{3}{|c|}{ cDNAs more highly expressed in the benign subtracted library ${ }^{a}$} & \multirow[b]{2}{*}{ Redundancy ${ }^{b}$} \\
\hline Level of expression & Name of cDNAs & $\begin{array}{c}\text { GenBank } \\
\text { Accession No. }\end{array}$ & \\
\hline \multirow[t]{4}{*}{ Highly differentially expressed clones (Level ratios > 15-fold): } & SIOOA2; & M87068 & \\
\hline & TGF- $\beta$ induced gene product (BIGH3); & M77349 & 16 \\
\hline & RTP & D87953 & 4 \\
\hline & EST & AA446686 & \\
\hline \multirow{3}{*}{$\begin{array}{l}\text { Significant differentially expressed clones (Level ratios between } \\
5-14.9 \text {-fold): }\end{array}$} & Human PAI-I mRNA; & X04744 & \\
\hline & Human annexin VIII; & M81844 & \\
\hline & KIAA 0205 & D86960 & \\
\hline \multirow[t]{13}{*}{ Differentially expressed clones (Level ratios between $2.0-4.9$ ): } & Human p cadherin; & $\times 63629$ & \\
\hline & Human mRNA for ets-2; & 104102 & \\
\hline & $\begin{array}{l}\text { Human XIST; } \\
\text { Human MMPI; }\end{array}$ & $\begin{array}{l}\text { M97I } 68 \\
\text { Z4848। }\end{array}$ & 3 \\
\hline & $\begin{array}{l}\text { Human MENI; } \\
\text { Novel sequence HII3; }\end{array}$ & AF00I893 & 4 \\
\hline & Prolylcarboxypeptidase; & LI3977 & \\
\hline & Vimentin 3; & M25246 & \\
\hline & Serum amyloid A protein; & $\times 5 / 445$ & \\
\hline & Xq28 genomic DNA in the region of the LICAM; & U52112 & \\
\hline & Lysyl hydroxylase 2 & U84573 & \\
\hline & 4 ESTs & AA234447 & \\
\hline & & AA022923 & \\
\hline & & AA249129 & \\
\hline & & H56754 & \\
\hline
\end{tabular}

cDNAs more highly expressed in the malignant subtracted library

\section{Level of expression}

Highly differentially expressed clones (ratio over 15-fold):

Significant differentially expressed clones (ratios between 5 - |4.9-fold):

\section{Name of cDNAs}

Cyclin DI:

Cleavage signal I protein:

Cytokeratin 8;

CAMP-dependent protein kinase type I-alpha subunit;

EMP2:

KIAAOI07;

M36/hAG2;

M4I EST;

M26I EST;

Orphan G protein-coupled receptor $(\mathrm{RDCl})$

pS2:

Soares testis cDNA clone 79584 EST

U2 snRNP auxiliary factor

Beige-like protein (BGL);

Guanine nucleotide-binding protein G-s, alpha subunit;

Death associated protein 5

Insulin induced protein I (INSIGI):

KIAA0286;

LIV-I;

Nuclear localization sequence receptor;

$\mathrm{Na}-\mathrm{K}-\mathrm{Cl}$ cotransporter;

Osteogenic protein:

TATA-binding protein associated factor $30 \mathrm{kDa}$ subunit; cDNA clone 2574 I8:

Soares pregnant uterus NbHPU EST;

Soares NhHMPu SI H. cDNA clone 8| |880;

Soares NhHMPu SI H. cDNA clone 68217;

ESTI00286;

cDNA clone 222365;

H cDNA clone 562572;

cDNA clone 648604:

HI05e3 gene;

$\mathrm{M} 3 \mathrm{I}$;

MIII

Differentially expressed clones (ratios between 2.0-4.9-fold):
Soares foetal lung NbHLI9W EST:

B-myb gene:

Small GTP-binding protein;

CD24 signal transducer;

\section{GenBank}

Accession No. Redundancy

\begin{tabular}{|c|c|}
\hline & \\
\hline$\times 59798$ & 4 \\
\hline M61199 & 5 \\
\hline$\times 74929$ & 8 \\
\hline M33336 & \\
\hline U52100 & 2 \\
\hline DI4663 & \\
\hline AF03845I & 4 \\
\hline & 4 \\
\hline U67784 & 2 \\
\hline X52003 & 2 \\
\hline AA460587 & \\
\hline M96982 & \\
\hline M83822 & \\
\hline X04409 & \\
\hline$\times 89713$ & \\
\hline U96876 & \\
\hline AB006624 & 2 \\
\hline U4I060 & 3 \\
\hline U28386 & \\
\hline U30246 & \\
\hline$\times 51801$ & \\
\hline U13991 & 2 \\
\hline N39924 & \\
\hline AAI50356 & 2 \\
\hline AA456246 & \\
\hline AA257072 & \\
\hline AA295। 39 & \\
\hline H864I 8 & \\
\hline$A A|| 2 \mid 40$ & \\
\hline AA223845 & \\
\hline AF006487 & \\
\hline W24624 & 2 \\
\hline$\times 13293$ & 2 \\
\hline L03303 & 3 \\
\hline
\end{tabular}

Continued 
Table 2 (Continued)

cDNAs more highly expressed in the malignant subtracted library

\begin{tabular}{|c|c|c|c|}
\hline Level of expression & Name of cDNAs & $\begin{array}{c}\text { GenBank } \\
\text { Accession No. }\end{array}$ & Redundancy ${ }^{b}$ \\
\hline & 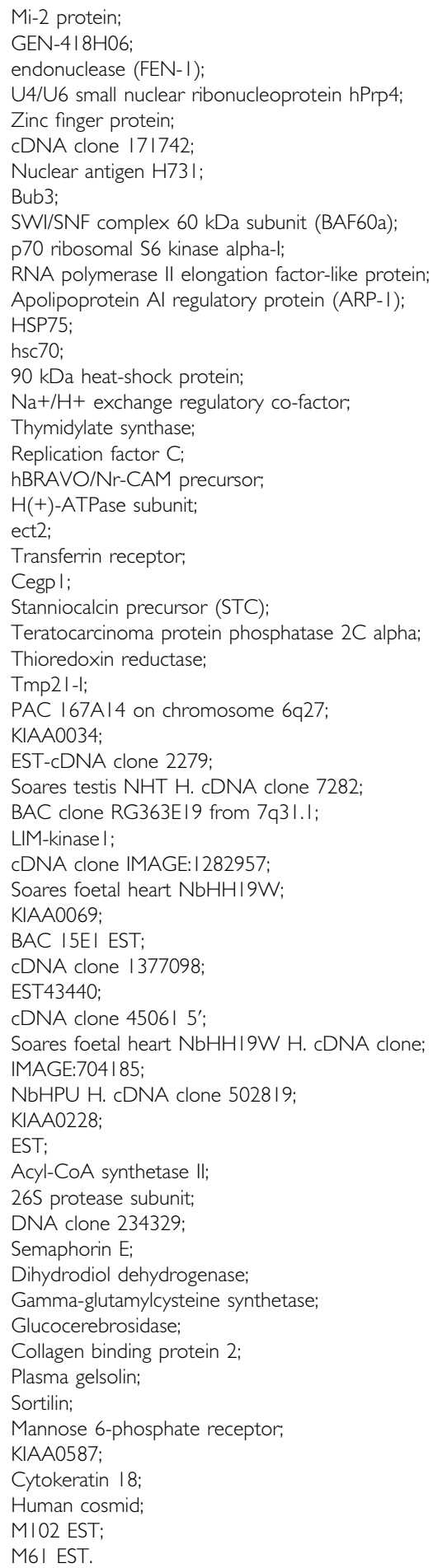 & 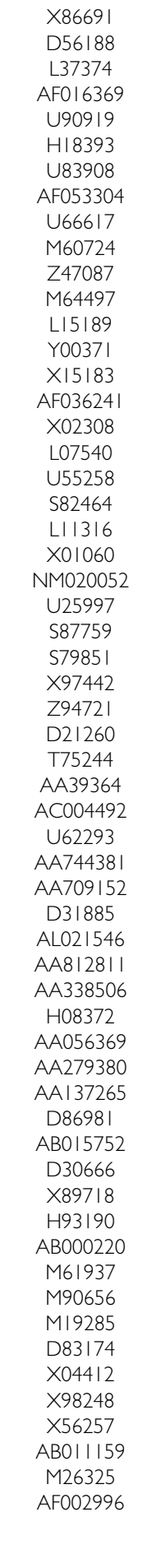 & $\begin{array}{l}2 \\
2 \\
5\end{array}$ \\
\hline
\end{tabular}

${ }^{a}$ A partial listing of cDNAs expressed at a higher level in the Huma 123 cells relative to the MCF-7 cells has been published previously (Liu et al, 2000). ${ }^{\mathrm{b}}$ Redundancy is the number of times the clone was picked from the library if greater than once.

antisense probe yielded strong hybridisation in the carcinoma cells of 10 carcinoma specimens and three specimens were negative.
There was no statistically significant correlation between M41 positivity and oestrogen receptor positivity for these samples $(P=1.00$, 


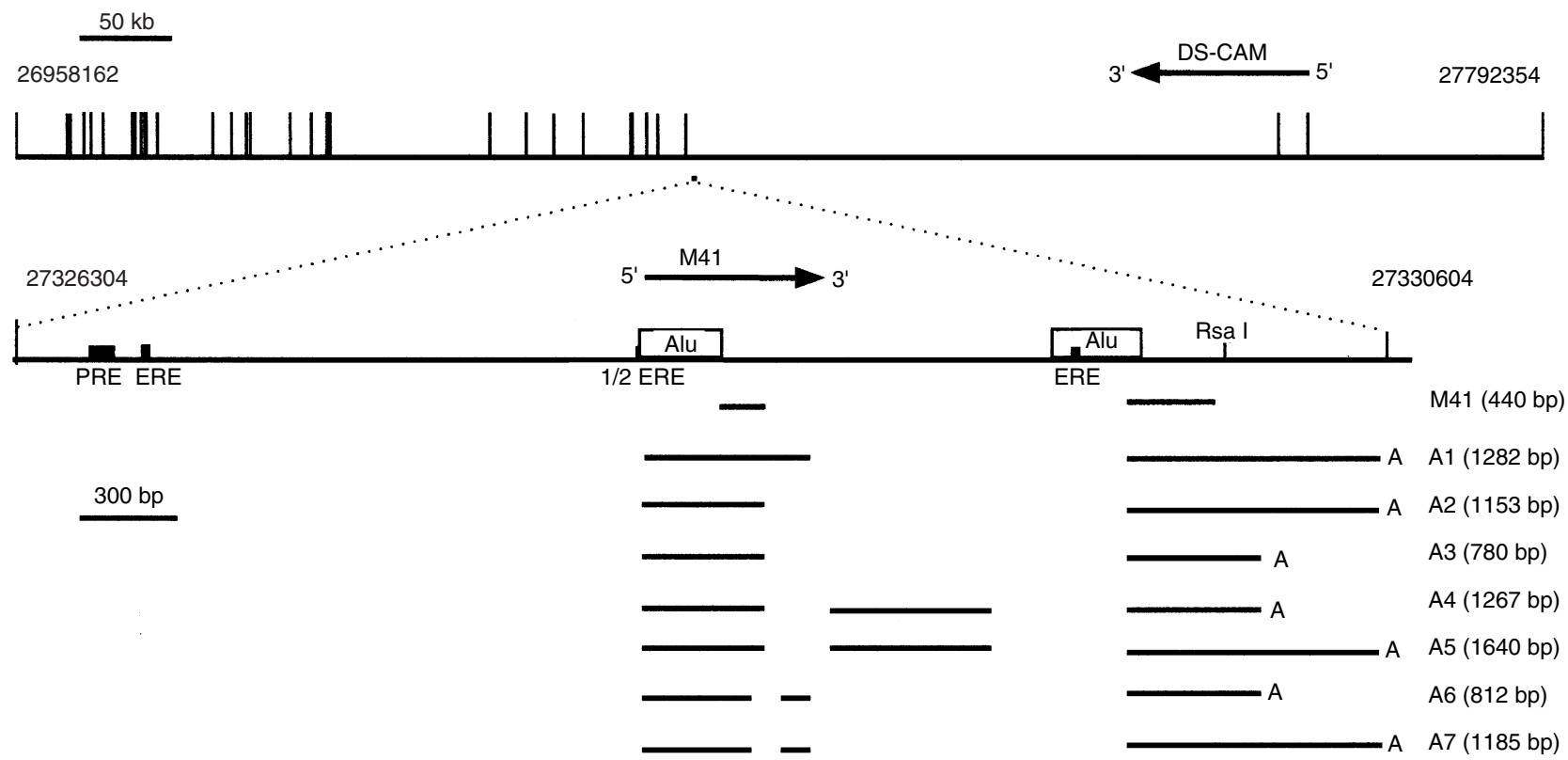

Figure 2 Alignment of the M4I gene and M4I transcripts. The gene region of chromosome 2 I q22.I is shown at the top with the exons of the DS-CAM gene shown as vertical bars. The location of the M4I gene is shown as a square to scale beneath the genomic DNA and expanded beneath. The location of response elements for oestrogen (ERE) and progesterone (PRE) and Alu sequences are shown. The region of the original M4I cDNA isolated from the MCF-7 subtracted library, and processing variants of M4I mRNA (AI-A7) obtained from the RACE reactions are shown as horizontal bars with gaps indicating the intronic regions. Numbering refers to the base number of contig NT_01 I512.3. The 5' intron exon boundaries revealed by the RACE reactions at 2732865I, 27328698, 27328827, 2732938I, and the $3^{\prime}$ intron exon boundaries at 27328749, 27328894, 2732982I (enumeration of contig NT_0I I I 2.3) all contained conserved GT / AG sequences and exhibited 62.5, 75, 87.5, 100, 75, 93.75, and $81.25 \%$ identity, respectively, to the consensus sequences for $5^{\prime}$ or $3^{\prime}$ intron exon boundaries (Mount, 1982). The symbols (A) at the ends of the lines indicate the poly(A) addition sites. Variants contained one of two alternative poly(A) addition sites (at 2733060 I and 27330228 of NT_0 I I I 2.3), with a consensus AATAAA poly(A)-addition signal, 29 and I 9 nucleotides upstream of the poly $(A)$-addition sites, respectively. The lengths of the proposed mRNA variants arising from the 7 alternatively-spliced exons correspond broadly to the sizes of two of the bands observed in the Northern blot for the mammary tumour cell line MCF-7 (Figure I), strongly suggesting that the RACE products are defining near full length mRNAs. Horizontal arrows indicate the direction of transcription of the genes.

Table 3 Genes located on chromosome 2 lq22.3 in the region of the M4I gene

\begin{tabular}{|c|c|c|c|c|}
\hline Start & Stop ${ }^{a}$ & Symbol & $+1-b$ & Full name ${ }^{c}$ \\
\hline 289926 & 39307551 & ETS2 & + & $\begin{array}{l}\text { v-ets avian erythroblastosis virus } \\
\text { E26 oncogene homologue } 2\end{array}$ \\
\hline 659576 & 39667567 & DSCR2 & - & Down syndrome critical region gene 2 \\
\hline 680250 & 39683601 & WDR9 & - & WD repeat domain 9 \\
\hline & 398 & HMGI4 & - & $\begin{array}{l}\text { High-mobility group (nonhistone } \\
\text { chromosomal) protein } 14\end{array}$ \\
\hline 39861720 & 39879066 & WRB & + & Tryptophan rich basic protein \\
\hline 70 & 40013 & SH3BGR & + & $\begin{array}{l}\text { SH3 domain binding glutamic } \\
\text { acid-rich protein }\end{array}$ \\
\hline 40137952 & 40143513 & B3GALT5 & + & $\begin{array}{l}\text { UDP-Gal:GIcNAc } \beta \text { I,3-galacto-syl- } \\
\text { transferase, polypeptide } 5\end{array}$ \\
\hline 40348176 & 40410103 & PCP4 & + & Purkinje cell protein 4 \\
\hline 40864053 & 40866326 & M4I & + & Identified in this paper \\
\hline & 41756844 & BACE2 & + & $\beta$-site APP-cleaving enzyme 2 \\
\hline 416 & 4166 & LOC82404 & + & $\begin{array}{l}\text { Hypothetical gene supported by } \\
\text { NM_00258I }\end{array}$ \\
\hline 41843016 & 41889940 & $M \times 2$ & + & $\begin{array}{l}\text { Myxovirus (influenza) resistance } 2 \\
\text { homolog of murine }\end{array}$ \\
\hline 41907238 & 41940262 & $M \times 1$ & + & $\begin{array}{l}\text { Myxovirus (influenza) resistance I, } \\
\text { homolog of murine (interferon- } \\
\text { inducible protein p78) }\end{array}$ \\
\hline
\end{tabular}

aLocation on chromosome 21 sequence. ${ }^{b}+$ or - strand of the DNA. ${ }^{c}$ Bold denotes M4I gene isolated in the MCF-7 subtracted library.

two-tailed Fisher Exact test). In contrast, there was no staining using the antisense probe on a benign fibroadenoma (Figure 3),
Table 4 M4I mRNA in breast tumour specimens

\begin{tabular}{|c|c|c|c|c|}
\hline Breast tumour specimens & $\begin{array}{c}\text { Total } \\
\text { number } \\
\text { tested }\end{array}$ & $\begin{array}{c}\text { M4l } \\
\text { mRNA } \\
\text { positive }\end{array}$ & $\begin{array}{c}\text { M4I } \\
\text { mRNA } \\
\text { negative }\end{array}$ & $\%$ positive \\
\hline Normal breast specimens & 6 & 1 & 5 & 17 \\
\hline Benign lesions & 10 & i & 9 & $10^{\mathrm{a}}$ \\
\hline Carcinomas & 26 & 15 & 11 & $58^{b}$ \\
\hline
\end{tabular}

${ }^{a}$ Not statistically significantly different from nromal ( $P=1$; Fisher exact test). ${ }^{\mathrm{b}}$ Statisti$P=0.028$; Fisher exact test) and benign lesions and normal ( $P=0.0$ I; Fisher exact test)

nor on four other fibroadenoma specimens examined. There was a statistically significant difference between the benign and malignant samples for M41 mRNA positivity $(P=<0.007$, two-tailed Fisher Exact test). Using a sensitive reverse transcript PCR (RTPCR) assay which yielded an M41-specific 147 bp product (Figure 4), RNA from 16 normal/benign, and 26 malignant breast tumour specimens were screened for the presence of M41 mRNA (Table 4). Although there was no correlation at all between the presence of RT - PCR detectable M41 mRNA-specific PCR product and oestrogen receptor positivity $(P=1.00$, Fisher exact test $)$ in the breast carcinoma specimens, M1 mRNA was detectable in 15 out of 26 malignant lesions, but there was an amplified product in only one out of five normal and one out of nine benign breast specimens. There was a strong statistically-significant difference between the occurrence of M41 mRNA in carcinoma specimens and its occurrence in normal/benign specimens $(P=0.01$, two-tailed Fisher exact test) or benign specimens $(P=0.028$, two-tailed Fisher exact test). 


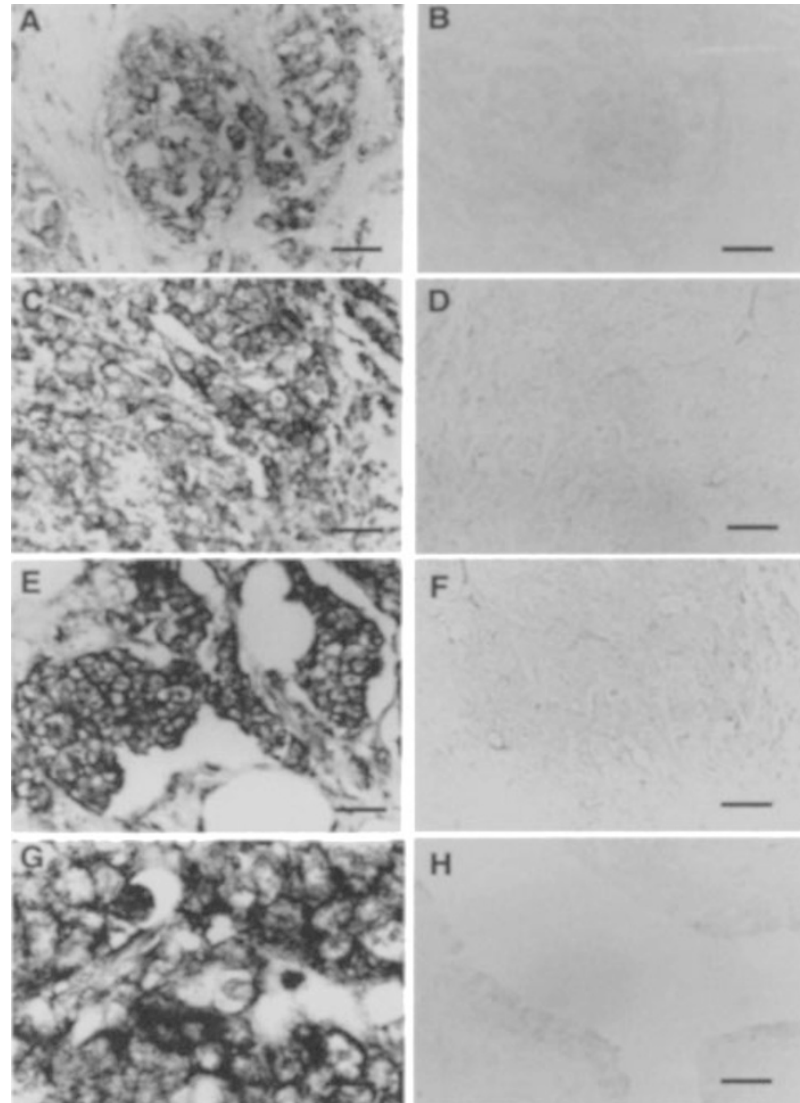

Figure 3 In situ hybridisation of M4I mRNA in human breast tumours. Histological sections of breast carcinoma specimens $(\mathbf{A}-\mathbf{G})$, and of one benign tumour specimen $(\mathbf{H})$ were subjected to in situ hybridisation using antisense $(\mathbf{A}, \mathbf{C}, \mathbf{E}, \mathbf{G}, \mathbf{H})$ or sense $(\mathbf{B}, \mathbf{D}, \mathbf{F})$ probes to $M 4 \mathrm{I}$ mRNA as described in Materials and Methods. The carcinoma cells in the specimens in $\mathbf{A}, \mathbf{C}, \mathbf{E}$ and $\mathbf{G}$ stain with an antisense probe of M4I CRNA, whereas there was no staining of adjacent sections of the specimens with sense M4I RNA probe (B, D, F). (H) shows an example of a fibroadenoma which did not stain with an antisense probe, in common with four other fibroadenomas tested. Magnification is $\times 231(\mathbf{A}-\mathbf{D}, \mathbf{F})$ or $\times 578(\mathbf{E}$, G, H). $\operatorname{Bars}=43 \mu \mathrm{m}(\mathbf{A}-\mathbf{D}, \mathbf{F})$ or $17 \mu \mathrm{m}(\mathbf{E}, \mathbf{G}, \mathbf{H})$.

\section{DISCUSSION}

Subtracted libraries have been constructed from well-characterised benign and malignant human breast tumour cell lines. The Huma 123 , typical of human benign tumour cells, is oestrogen receptor negative and was compared with the less-malignant oestrogen receptor positive MCF-7 cell line, in preference to a more-malignant oestrogen receptor negative one such as MDA-MB-231, which lacks epithelial markers characteristic of breast carcinoma cells (Engel and Young, 1978). Although it was expected that oestrogen responsive cDNAs would be present in an MCF-7 library, the use of the better-defined breast epithelial MCF-7 cells reduced the likelihood of isolating cell-culture-related cDNAs. The libraries were discrete, and subtracted cloned cDNAs were differentially expressed when tested by reverse Northern and Northern hybridisation techniques. Although some cDNAs were differentially expressed by up to 36 -fold, $76 \%$ and $83 \%$ of cDNAs in the benign and malignant libraries, respectively, were differentially expressed at a level of greater than two-fold. In both libraries, the majority of cloned cDNAs $(66 \%$ and $56 \%$ for the benign and malignant subtracted libraries, respectively) represented products of previously-described genes. However, 28\% of the sequenced clones in the benign cell library represented ESTs, but for the malignant library this proportion was somewhat higher at $41 \%$, perhaps reflecting a greater number of previously-uncharacterised genes differentially-expressed in the malignant cells relative to the more tightly regulated cells of benign tumour origin. Only small proportions of the libraries were picked for sequencing. The observation that in each library, the majority of randomly picked cloned cDNAs were both differentially expressed and unique sequences suggests that these large libraries represent resources which contain further differentially-expressed cDNAs.

A recent study, using MCF-7 cells grown in the presence or absence of steroids as the starting material for subtraction, yielded 14 oestrogen responsive cDNAs (Ghosh et al, 2000). In another, the dissimilar oestrogen-receptor positive MCF-7 cell line and the oestrogen receptor negative, breast carcinoma cell line MDA-MB231 yielded only 28 separate cDNAs (Kuang et al, 1998). In the present experiments, over 100 cDNAs have been isolated so far, possibly suggesting greater variation in gene expression between a benign and a malignant mammary cell line, than between two malignant mammary cell lines (Kuang et al, 1998). However, a small subset of cloned cDNAs found to be elevated in the present malignant library was also differentially-expressed in the previously-reported screen between the MCF-7 cells and MDAMB-231 cells (Kuang et al, 1998), including cytokeratins 8 and 18 and CD 24 (Yang et al, 1999). Since the Huma 123 cell line and the MCF-7 cell lines used in the present study have the same oestrogen receptor status as the MDA-MB-231 cells and the MCF-7 respectively (Kuang et al, 1998), it is likely that the mRNAs represented by these cloned cDNAs, are associated with the differing oestrogen receptor status of the presently-used cell lines. Furthermore, other ER-dependent mRNAs, including Cyclin D1 (Altucci et al, 1996), pS2 (Masiakowski et al, 1982) and pLIV-1 (Manning et al, 1988), were also present in the malignant subtracted library.

cDNAs from the present libraries that have been described previously suggest that the libraries do contain cDNAs with relevance in the development of breast cancer. For example, overexpression of Cyclin D1 has been shown to distinguish breast carcinomas and in situ breast lesions from benign lesions (WeinstatSaslow et al, 1995). Amongst other cDNAs up-regulated in the malignant cell library, were those corresponding to mRNAs for a putative G-protein-coupled receptor (Libert et al, 1989), for proteins associated with the mitotic spindle checkpoint, BUB3 (Brady and Hardwick, 2000) and with chromatin remodelling (Wang et al, 1996; Zhang et al, 1998; Vignali et al, 2000). Two cDNAs (LIM kinase and BUB3), which are differentially-expressed in the present malignant library, have also been found to be differentially expressed in a subtracted library representing cDNAs expressed in a pathologically homogeneous breast carcinoma specimen subtracted with cDNA from 50000 ductal-carcinoma-in-situ cells microdissected from the surrounding normal tissue (Liu, 2001). Although the dependence of expression of the mRNAs for these cloned cDNAs on oestrogen is not known, the present work clearly identifies many relevant cloned cDNA targets for further investigation.

The subtracted library of cDNAs down-regulated in the MCF-7 cells relative to the Huma 123 cells contained a cDNA corresponding to the mRNA for an EF-hand protein, S100A2, which was shown previously to be abundantly expressed in both normal breast and benign breast tumour specimens (Liu et al, 2000), but only detectable in less than $15 \%$ of malignant breast cancer specimens tested. This result suggests that the suppression subtractive hybridisation produces libraries containing cDNAs differentially expressed between benign and malignant cells.

The library of cDNAs up-regulated in MCF-7 cells relative to the benign Huma 123 cells contained ESTs that exhibited oestrogen dependence. One such cloned cDNA, M41, corresponds to a transcript of a previously unmapped gene located on chromosome 21q22.3. $5^{\prime}$ and $3^{\prime}$ RACE experiments showed that M41 mRNA 
A

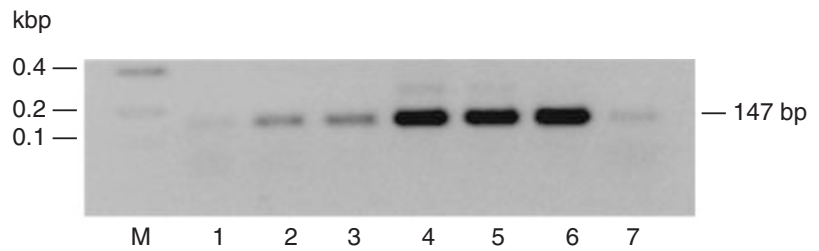

B

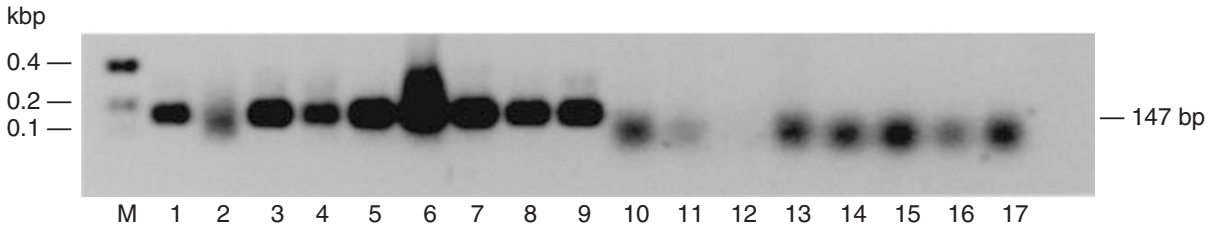

Sample MCF-7 IDC IDC IDC IDC IDC IDC IDC IDC N B IDC IDC - - B $N$

$\mathrm{ER}+++++++++\mathrm{N} / \mathrm{A} \mathrm{N} / \mathrm{A}++\mathrm{N}_{+}$N/A N/A

Figure 4 Occurrence of M4I mRNA in benign and malignant human mammary cell lines and breast tumour specimens by RT-PCR. Total RNA from human mammary cell lines. Normal breast derived Huma 7 (A, lane I), benign breast derived Huma 123 (lane 2), Huma I09 (A, lane 3), and breast carcinoma-derived cell lines, MCF-7 (A, lane 4), T47-D (A, lane 5), ZR-75 (A, lane 6), MDA-MB-23I (A, lane 7), and total RNA from breast carcinoma specimens (B, lanes 2-9, I2- I3), normal breast specimens (B, lanes I0 and 17), and benign breast specimens (B, lanes II and I6) were amplified by RT - PCR using primers specific for M4I yielding PCR products of 147 bp. (B), lanes 14 and I5 are the negative RT-PCR controls, and lane I is MCF-7 cell line RNA as positive control. The resulting RT-PCR products were subjected to agarose gel electrophoresis and stained with ethidium bromide, as described in Materials and Methods. Lane M, DNA molecular weight markers. The estrogen receptor status of the specimens is shown beneath panel B as + , positive or -, negative. N/A is not available. The faint bands in $\mathbf{A}$, lanes I -3 and 7 arise from the amplification of a low, otherwise undetectable, level of M4I mRNA in these specimens. The diffuse bands in $\mathbf{B}$, lanes 2 , and $10-17$ at $<100$ bp are caused by primer dimers. DNA sequencing of the 147 bp band confirmed its identity with the expected sequence of the amplified band.

possesses a complex pattern of spliced variants in the MCF-7 cells, some of which contain short open-reading-frames which can be translated into protein using a coupled in vitro transcription translation system (not shown). However, the splice variants were not sufficiently different in size to be individually distinguishable in the Northern blotting experiments. The individual introns and exons of this new gene have now been precisely mapped onto chromosome 21 contigs.

M41 mRNA was shown to be produced by the carcinoma cells of breast cancer specimens using in situ hybridisation, and, using a PCR assay, M41 mRNA was found not to be statistically significantly correlated with the presence of oestrogen receptor, nor with the immunocytochemical detection of the oestrogen-responsive progesterone receptor (not shown) in a panel of carcinoma specimens. Thus, although M41 mRNA relates to oestrogen receptor status in the malignant breast-derived cell lines tested, in the carcinoma specimens, the relationship is stronger between benign and malignant than between oestrogen receptor positive and negative. These results probably relate to the complexity of oestrogen receptor regulation of gene expression. It is the results with the carcinoma specimens that are likely to be more important. A similar weakening of correlation with ER status of carcinoma specimens has been found for two different cDNAs, pDZK1 and GREB1, which also showed a strong correlation with ER in cell lines (Ghosh et al, 2000), but which exhibited a much weaker correlation with oestrogen receptor positivity in carcinoma specimens. This lack of correlation between oestrogen responsive cDNAs in MCF-7 cells and carcinoma specimens, and the variability of patterns of gene expression in breast carcinomas has recently also been reported using array technology (Gruvberger et al, 2001). The M41 gene contains an oestrogen response element associated with an intronic alu repeat sequence. Such variant alu-DNA repeats, that can act as oestrogen and other steroid hormone response elements, have been described previously (Norris et al, 1995; Babich et al, 1999). The M41 gene alu-associated ERE is of the inverted repeat type with a 17 nucleotide separation (IR-17) as described by Babich et al (1999). Whilst it is known that similar elements can activate reporter gene activity in a hormone dependent manner in cultured cells (Norris et al, 1995; Babich et al, 1999) and also bind proteins in vitro from nuclear extracts of cultured cells (Babich et al, 1999), little is known of their activity in carcinoma cells that have not been subjected to cell culture. In the present experiments on carcinoma specimens, the statistically-significant difference in the expression of M41 mRNA between malignant human breast specimens and either benign or benign and normal breast specimens, but the lack of correlation with oestrogen receptor status, suggests that M41 mRNA is upregulated during the malignant progression of carcinomas, by an oestrogen-independent mechanism.

\section{ACKNOWLEDGEMENTS}

We thank Clatterbridge Cancer Research Trust for a studentship to Dong Liu. Additional financial support from the Cancer and Polio Research Fund and an ORS award from HEFC are gratefully acknowledged. We thank the CANDIS Cancer Tissue Bank Research Centre for tissue specimens, Drs Mike Davies, Fiona Gibbs and Nigel Halliwell for help with DNA sequencing, Angela Platt-Higgins for help with tissue sectioning, Maureen Wilde for help with photography and Dr Chris Green for scientific discussion. 


\section{REFERENCES}

Altschul SF, Gish W, Miller W, Myers EW, Lipman D (1990) Basic local alignment search tool. J Mol Biol 215: $403-410$

Altucci L, Addeo R, Cicatiello L, Dauvois S, Parker MG, Truss M, Beato M, Sica V, Bresciani F, Weisz A (1996) $17 \beta$-estradiol induces cyclin D1 gene transcription, p36D1-p34cdk4 complex activation and p105Rb phosphorylation during mitogenic stimulation of $\mathrm{G}(1)$-arrested human breast cancer cells. Oncogene 12: $2315-2324$

Babich V, Aksenov N, Alexeenko V, Oei SL, Buchlow G, Tomilin N (1999) Association of some potential hormone response elements in human genes with the Alu family repeats. Gene 239: $341-349$

Barraclough R (1998) Calcium-binding protein S100A4 in health and disease. Biochim Biophys Acta 1448: $190-199$

Brady DM, Hardwick KG (2000) Complex formation between Mad1p, Bublp and Bub3p is crucial for spindle checkpoint function. Curr Biol 10: 675678

Briand P, Petersen OW, Van Deurs B (1987) A new diploid non-tumorigenic human breast epithelial cell line isolated and propagated in chemicallydefined medium. in vitro 23: $181-188$

Cailleau R, Young R, Olivé M, Reeves WJ (1974) Breast tumour lines from pleural effusions. J Natl Cancer Inst 53: 661-674

Davies BR, Davies MPA, Gibbs FEM, Barraclough R, Rudland PS (1993) Induction of the metastatic phenotype by transfection of a benign rat mammary epithelial cell line with the gene for $\mathrm{p} 9 \mathrm{Ka}$, a rat calcium-binding protein but not with the oncogene EJ ras-1. Oncogene 8: 999-1008

Engel LW, Young NA (1978) Human breast carcinoma cells in continuous culture: a review. Cancer Res 38: $4327-4339$

Fearon ER, Vogelstein B (1990) A genetic model for colorectal tumorigenesis. Cell 61: $759-767$

Feinberg AP, Vogelstein B (1984) A technique for radiolabelling DNA restriction endonuclease fragments to high specific activity. Anal Biochem 137: $266-267$

Ghosh MG, Thompson DA, Weigel RJ (2000) PDZK1 and GREB1 are estrogen-regulated genes expressed in hormone-responsive breast cancer. Cancer Res 60: 6367-6375

Gruvberger S, Ringnér M, Chen Y, Panavally S, Saal L, Borg A, Fernö M, Peterson C, Meltzer P (2001) Estrogen receptor status in breast cancer is associated with remarkably distinct gene expression patterns. Cancer Res 61: $5979-5984$

Ke Y, Fernig DG, Wilkinson MC, Winstanley JHR, Smith JA, Rudland PS, Barraclough R (1993) The expression of basic fibroblast growth factor and its receptor in cell lines derived from normal human mammary gland and a benign mammary lesion. J Cell Sci 106: 135-143

Kuang WW, Thompson DA, Hoch RV, Weigel RJ (1998) Differential screening and suppression subtractive hybridization identified genes differentially expressed in an estrogen receptor- positive breast carcinoma cell line. Nucleic Acids Res 26: 1116-1123

Laborda J (1991) 36B4 cDNA used as an estradiol-independent mRNA control is the cDNA for human acidic ribosomal phosphoprotein PO. Nucleic Acids Res 19: 3998

Libert F, Parmentier M, Lefort A, Dinsart C, Van Sande J, Maenhaut C, Simons MJ, Dumont JE, Vassart G (1989) Selective amplification and cloning of four new members of the $\mathrm{G}$ protein-coupled receptor family. Science 244: $569-572$

Liu D (2001) The Identification of Genes Differentially Expressed in Human Breast Lesions. Ph.D. Thesis, University of Liverpool

Liu D, Rudland PS, Sibson DR, Platt-Higgins A, Barraclough R (2000) Expression of calcium-binding protein S100A2 in breast lesions. $\mathrm{Br} J$ Cancer 83: $1473-1479$
Manning DL, Daly RJ, Lord PG, Kelly KF, Green CD (1988) Effects of oestrogen on the expression of a $4.4 \mathrm{~kb}$ mRNA in the ZR-75-1 human breast cancer cell line. Mol Cell Endocrinol 59: 205-212

Martin K, Kritzman DM, Price LM, Koh B, Kwan CP, Zhang XH, Mackay A, O'Hare MJ, Kaelin DM, Mutter GL, Pardee AB, Sager R (2000) Linking gene expression patterns to therapeutic groups in breast cancer. Cancer Res 60: $2232-2238$

Masiakowski P, Breathnach R, Bloch J, Gannon F, Krust A, Chambon P (1982) Cloning of cDNA sequences of hormone-regulated genes from the MCF-7 human breast cancer cell line. Nucleic Acids Res 10: 7895 - 7903

Mount S (1982) A catalogue of splice junction sequences. Nucleic Acids Res 10: $459-472$

Norris J, Fan D, Aleman C, Marks JR, Futreal PA, Wiseman RW, Iglehart JD, Deininger PL, McDonnell DP (1995) Identification of a new subclass of Alu DNA repeats which can function as estrogen receptor-dependent transcriptional enhancers. J Biol Chem 270: 22777-22782

Nowell P (1986) Mechanisms of tumor progression. Cancer Res 46: 2203 2207

Platt-Higgins AM, Renshaw CA, West CR, Winstanley JHR, De Silva Rudland S, Barraclough R, Rudland PS (2000) Comparison of the metastasis-inducing protein S100A4 (p9Ka) with other prognostic markers in human breast cancer. Int J Cancer (Pred Oncol) 89: 198-208

Rudland PS (1993) Epithelial stem cells and their possible role in the development of the normal and diseased human breast. Histol Histopath 8: $385-404$

Rudland PS, Ollerhead G, Barraclough R (1989) Isolation of simian virus 40 transformed human mammary epithelial stem cell line that can differentiate to myoepithelial-like cells in culture and in vivo. Develop Biol 136: $167-180$

Sambrook J, Fritsch EF, Maniatis T (1989) Molecular Cloning: A Laboratory Manual. Cold Spring Harbor, NY: Cold Spring Harbor Laboratory Press

Soule HD, Vazquez A, Long A, Albert S, Brennan MA (1973) Human cell line from a pleural effusion derived from a breast carcinoma. J Natl Cancer Inst 51: $1409-1413$

Taylor SL, Platt-Higgins A, Rudland PS, Winstanley JHR, Barraclough R (1998) Cytoplasmic staining of c-erbB-2 is not associated with the presence of detectable c-erbB-2 mRNA in breast cancer specimens. Int J Cancer 76: $459-463$

Vignali M, Hassan AH, Neely KE, Workman JL (2000) ATP-dependent chromatin-remodeling complexes. Mol Cell Biol 20: 1899-1910

Wang W, Xue Y, Zhou S, Kuo A, Cairns BR, Crabtree GR (1996) Diversity and specialization of mammalian SWI/SNF complexes. Genes Dev 10: $2117-2130$

Weinstat-Saslow D, Merino MJ, Manrow RE, Lawrence JA, Bluth RF, Wittenbel KD, Simpson JF, Page DL, Steeg PS (1995) Overexpression of cyclin D mRNA distinguishes invasive and in situ breast carcinomas from nonmalignant lesions. Nature Med 1: 1257-1260

Yang GP, Ross DT, Kuang WW, Brown PO, Weigel RJ (1999) Combining SSH and cDNA microarrays for rapid identification of differentially expressed genes. Nucleic Acids Res 27: 1517-1523

Zhang Y, LeRoy G, Seelig H-P, Lane WS, Reinberg D (1998) The dermatomyositis-specific autoantigen $\mathrm{Mi} 2$ is a component of a complex containing histone deacetylase and nucleosome remodeling activities. Cell 95: $279-289$ 